\title{
Toll-like receptor and antimicrobial peptide expression in the bovine endometrium
}

\author{
Darren Davies' ${ }^{1}$, Kieran G Meade ${ }^{2}$, Shan Herath ${ }^{1}$, P David Eckersall3, \\ Deyarina Gonzalez ${ }^{4}$, John O White ${ }^{4}$, R Steven Conlan ${ }^{4}$, Cliona O'Farrelly ${ }^{2}$ \\ and I Martin Sheldon*4
}

\begin{abstract}
Address: ${ }^{1}$ Department of Veterinary Clinical Sciences, Royal Veterinary College, Royal College Street, London, NW1 0TU, UK, ${ }^{2}$ Comparative Immunology Group, School of Biochemistry and Immunology, Trinity College Dublin, Dublin, Ireland, ${ }^{3}$ Institute of Comparative Medicine, Faculty of Veterinary Medicine, University of Glasgow, Bearsden Rd, Glasgow, G61 1QH, UK and ${ }^{4}$ Institute of Life Science, School of Medicine, Swansea University, Swansea, SA2 8PP, UK

Email: Darren Davies - dadavies@live.co.uk; Kieran G Meade - meadek@tcd.ie; Shan Herath - sherath@rvc.ac.uk; P David Eckersall - p.d.eckersall@vet.gla.ac.uk; Deyarina Gonzalez - d.gonzalez@swansea.ac.uk; John O White - J.O.White@Swansea.ac.uk; R Steven Conlan - R.S.Conlan@Swansea.ac.uk; Cliona O'Farrelly - cliona.ofarrelly@tcd.ie; I Martin Sheldon* - I.M.Sheldon@Swansea.ac.uk

* Corresponding author
\end{abstract}

Published: 18 November 2008

Reproductive Biology and Endocrinology 2008, 6:53 doi:10.1/86/1477-7827-6-53

This article is available from: http://www.rbej.com/content/6/1/53

(C) 2008 Davies et al; licensee BioMed Central Ltd.

This is an Open Access article distributed under the terms of the Creative Commons Attribution License (http://creativecommons.org/licenses/by/2.0), which permits unrestricted use, distribution, and reproduction in any medium, provided the original work is properly cited.

\begin{abstract}
Background: The endometrium is commonly infected with bacteria leading to severe disease of the uterus in cattle and humans. The endometrial epithelium is the first line of defence for this mucosal surface against bacteria and Toll-like receptors (TLRs) are a critical component of the innate immune system for detection of pathogen associated molecular patterns (PAMPs). Antimicrobial peptides, acute phase proteins and Mucin-I (MUC-I) also provide non-specific defences against microbes on mucosal surfaces. The present study examined the expression of innate immune defences in the bovine endometrium and tested the hypothesis that endometrial epithelial cells express functional receptors of the TLR family and the non-specific effector molecules for defence against bacteria.
\end{abstract}

Methods: Bovine endometrial tissue and purified populations of primary epithelial and stromal cells were examined using RT-PCR for gene expression of TLRs, antimicrobial peptides and MUC-I. Functional responses were tested by evaluating the secretion of prostaglandin $E_{2}$ and acute phase proteins when cells were treated with bacterial PAMPs such as bacterial lipopolysaccharide (LPS) and lipoproteins.

Results: The endometrium expressed TLRs I to 10, whilst purified populations of epithelial cells expressed TLRs I to 7 and 9, and stromal cells expressed TLRs I to 4, 6, 7,9 and I0. The TLRs appear to be functional as epithelial cells secreted prostaglandin $E_{2}$ in response to bacterial PAMPs. In addition, the epithelial cells expressed antimicrobial peptides, such as Tracheal and Lingual Antimicrobial Peptides (TAP and LAP) and MUC-I, which were upregulated when the cells were treated with LPS. However, the epithelial cells did not express appreciable amounts of the acute phase proteins haptoglobin or serum amyloid $\mathrm{A}$.

Conclusion: Epithelial cells have an essential role in the orchestration of innate immune defence of the bovine endometrium and are likely to be the key to prevention of endometrial infection with bacteria. 


\section{Background}

Microbial infection of the female genital tract is an important cause of disease, infertility and mortality in mammals, particularly cattle and humans. Bos taurus is a biologically relevant model to study female genital tract disease because infections are ubiquitous after parturition, often leading to uterine disease. Up to $40 \%$ of animals develop clinical metritis within 2 weeks of parturition and endometritis persists for at least 3 weeks in about $20 \%$ of cattle $[1,2]$. The microbes most commonly associated with postpartum uterine disease are Escherichia coli, Arcanobacterium pyogenes and bovine herpesvirus 4 (BoHV-4) [2-4]. E. coli infection paves the way for subsequent infection with $A$. pyogenes and activates BoHV-4 replication $[5,6]$. The first line of defence against these infections in the female genital tract is the endometrium, which is a mucosa comprising of a layer of single columnar epithelial cells overlying a stroma that contains blood vessels and immune cells as well as endometrial stromal cells. The initial defence of the endometrium against microbes is dependent on innate immune systems, including Toll-like receptors (TLRs), antimicrobial peptides (AMPs), and acute phase proteins (APPs) $[7,8]$. Furthermore, the immune defence of the endometrium is regulated by the ovarian steroids, oestradiol and progesterone [9]. Bos taurus endometrium presents an advantage over human or mouse models for studying innate immunity because it is possible to obtain purified populations of epithelial or stromal cells that are not contaminated by other immune cells [10].

TLRs recognise pathogen associated molecular patterns (PAMPs), and 10 members of the receptor family are widely expressed in the mammalian genome [11]. TLR1, TLR2, and TLR6 recognise bacterial lipids such as lipoteichoic acid (LTA), whereas TLR3, TLR7, TLR8, and TLR9 recognize nucleic acids, often from viruses, although TLR9 also recognises bacterial DNA. TLR4 recognizes lipopolysaccharide (LPS) from Gram-negative bacteria such as $E$. coli, and TLR5 binds flagellin, but the ligand for TLR10 is still not known. The expression of TLRs in the endometrium has been examined in humans $[12,13]$. However, in cattle, only TLR4 has been studied in detail in endometrial cells, where LPS treatment was characterised by the secretion of prostaglandin $E_{2}[14]$.

AMPs are an ancient component of the immune system, of which $\beta$-defensins are the main family, and are particularly important for mucosal immunity [15]. Indeed, the first mammalian $\beta$-defensin, Tracheal Antimicrobial Peptide (TAP), was identified in cattle. The Bos taurus genome sequence has been exploited to expand the AMP family to 57 putative $\beta$-defensin genes - the most in any mammal [16]. In a study screening several bovine tissues, the uterus was found to express genes encoding Lingual Antimicro- bial Peptide $(L A P)$, Bovine neutrophil $\beta$-defensins (BNBD4, DEFB5), and novel bovine $\beta$-defensins (BBD19, $B B D 123$ and BBD124) [17]. However, such uterine samples also contain a complex range of cell types, so it is not clear if AMPs are expressed by endometrial cells and have a role in the immune defence of the endometrium.

Acute phase proteins (APPs) such as haptoglobin and serum amyloid A provide non-specific protection against microbes [18]. These APPs are usually produced by the liver, but localised expression has been found in the genital tract of rodents and expression was regulated by the sex steroids $[19,20]$. Mucin-1 (MUC-1) is an epithelial cell glycosylated transmembrane protein that may also have a role in microbial defence of the endometrium [21]. Although MUC-1 expression has not been evaluated in the bovine uterus, it is expressed by epithelial cells of the human and ovine endometrium [22,23].

Our central paradigm is that the endocrine cells of the endometrium play the key role in the defence of the uterus against microbial infection. The present study tested the hypothesis that endometrial epithelial cells express functional receptors of the TLR family and the non-specific effector molecules for defence against bacteria. The first objective was to establish if bovine endometrium expresses TLRs. The next question was which endometrial cells express functional receptors of the TLR family and the non-specific effector molecules such as AMPs, APPs, and MUC-1 for defence against bacteria.

\section{Methods \\ Tissues and cells}

Uteri from postpubertal non-pregnant cattle were collected at a local abattoir immediately after slaughter and kept on ice until further processing in the laboratory. These animals had no evidence of genital disease based on visual inspection and attempted culture of bacteria using standard microbiological techniques. The physiological stage of the reproductive cycle for each genital tract was determined by observation of the ovarian morphology [24]. Tracts with an early corpus luteum (Stage 1) were selected for endometrial tissue and cell culture. Endometrium was carefully dissected free from the underlying tissue and immediately used for cell isolation or put in RNAlater (Qiagen, Crawley, UK) for isolation of mRNA to examine gene expression.

Cell isolation was performed as previously described using only the endometrium from the horn ipsilateral to the corpus luteum [14]. Briefly, tissue was digested in 25 $\mathrm{ml}$ sterile filtered digestive solution, which was made by dissolving $50 \mathrm{mg}$ trypsin III (Roche, Lewes, UK), $50 \mathrm{mg}$ collagenase II (Sigma, Poole, UK), 100 mg BSA (Sigma), 
and $10 \mathrm{mg}$ DNase I (Sigma) in $100 \mathrm{ml}$ phenol-red-free Hanks Balanced Salt Solution (HBSS; Sigma). After a 1.5$\mathrm{h}$ incubation in a shaking water bath at $37^{\circ} \mathrm{C}$, the cell suspension was filtered through a $40-\mu \mathrm{m}$ mesh (Fisher Scientific, Loughborough, UK) to remove undigested material, and the filtrate was resuspended in phenol-red-free HBSS containing 10\% fetal bovine serum (FBS; Sigma) and 3 $\mu \mathrm{g} / \mathrm{ml}$ trypsin inhibitor (Sigma) (washing medium). The suspension was centrifuged at $100 \times g$ for $10 \mathrm{~min}$ and, after two further washes in washing medium, the cells were resuspended in RPMI 1640 medium (Sigma) containing $10 \%$ fetal bovine serum (PAA laboratories), 50 $\mathrm{IU} / \mathrm{ml}$ penicillin, $50 \mu \mathrm{g} / \mathrm{ml}$ streptomycin, and $2.5 \mu \mathrm{g} / \mathrm{ml}$ amphotericin B (Sigma). The cells were plated at a density of $1 \times 10^{5}$ cells in $2 \mathrm{ml}$ per well using 24-well plates (Nunc, Rochester, NY, USA). To obtain separate stromal and epithelial cell populations, the cell suspension was removed $18 \mathrm{~h}$ after plating, which allowed selective attachment of stromal cells, and the removed cell suspension was then replated and incubated allowing epithelial cells to adhere. Stromal and epithelial cell populations were distinguished by cell morphology and the purity was greater than $95 \%$ as determined by microscopy and the differential production of prostaglandins - stromal cells do not produce prostaglandin $\mathrm{F}_{2 \alpha}[14]$. The culture media was changed every $48 \mathrm{~h}$ until the cells reached confluence. All cultures were maintained at $37^{\circ} \mathrm{C}, 5 \% \mathrm{CO}_{2}$ in air, in a humidified incubator.

Purified populations of stromal and epithelial cells were collected and stored immediately in RNAlater for mRNA isolation to examine gene expression. To examine if the TLRs were function, 90\% confluent stromal and epithelial cells were challenged for $24 \mathrm{~h}$ with bacterial PAMPs at concentrations recommended by the manufacture. The PAMPs were $1 \mu \mathrm{g} / \mathrm{ml}$ O55:B5 LPS (Sigma) or $1 \mu \mathrm{g} / \mathrm{ml}$ ultrapurified O111:B4 LPS (InvivoGen, San Diego, CA, USA) for TLR4; $1 \mu \mathrm{g} / \mathrm{ml}$ Pam3CSK4 synthetic bacterial lipoprotein for TLR2 and TLR1 (InvivoGen); $1 \mu \mathrm{g} / \mathrm{ml}$ purified lipoteichoic acid from Staphylococcus aureus for TLR2 (LTA, InvivoGen); or, $5 \mu \mathrm{g} / \mathrm{ml}$ LPS-free DNA from E. coli for TLR9 (DNA, InvivoGen). The culture supernatants were harvested and frozen at $-20^{\circ} \mathrm{C}$ until used to measure prostaglandin $E_{2}$ as previously described [14]. Briefly, samples were diluted in $0.05 \mathrm{M}$ Tris buffer containing $0.1 \%$ gelatin and $0.01 \%$ sodium azide. Standards and tritiated tracers for the prostaglandin were purchased from Sigma and Amersham International PLC (Amersham, Little Chalfont, Buckinghamshire, UK), respectively. The antiserum was a generous gift from Prof. N. L. Poyser (University of Edinburgh, Edinburgh, UK), the limit of detection was $2 \mathrm{pg} /$ tube, and intra-assay and inter-assay coefficients of variation were 4.4 and $7.8 \%$, respectively. The effect of the PAMPs on cell survival was evaluated by counting the number of live epithelial and stromal cell using a haemocytometer and the Trypan Blue exclusion method.

To examine AMP, MUC-1 and APP expression stromal and epithelial cells were collected and stored immediately in RNAlater for mRNA isolation. To test if these molecules have a role in the endometrial response to bacteria, the cells were also treated for $24 \mathrm{~h}$ with $1 \mu \mathrm{g} / \mathrm{ml}$ O55:B5 LPS (Sigma), progesterone (Sigma), or oestradiol (Sigma), as indicated in Results.

\section{Toll-like receptors}

Total RNA was isolated with the RNeasy Mini kit (Qiagen) from the samples stored in RNAlater, and DNase treated with RQ1 RNase-free DNase (Promega, Madison, USA). The RNA quality and quantity was determined by spectrophotometry using a NanoDrop-1000 (Labtech Int. Ltd, Ringmer, UK) and $1 \mu \mathrm{g}$ reverse transcribed using SuperScript II RT (Invitrogen, Paisley, UK) to synthesise first strand cDNA, according to the manufacturers' instructions.

Intron-spanning gene-specific primers for real-time polymerase chain reaction (RT-PCR) were designed for TLRs 1 to 10 coding sequences published in the National Center for Biotechnology Information database (NCBI, Bethesda, MD, USA) with the aid of Primer3 software [25], and purchased from MWG (Ebersberg, Germany). Details of the PCR primer sequences are provided in Table 1 , and each product was sequenced to confirm specificity. Amplification of cDNA was performed using the following conditions: an initial denaturation at $94^{\circ} \mathrm{C}$ for $5 \mathrm{~min}$; followed by 38 cycles of $94^{\circ} \mathrm{C}$ for $30 \mathrm{sec}, 55-56^{\circ} \mathrm{C}$ (depending on primer pair $\mathrm{T}_{\mathrm{M}}$ ) for $30 \mathrm{sec}$ and $72^{\circ} \mathrm{C}$ for 30 sec; with a final extension at $72^{\circ} \mathrm{C}$ for $5 \mathrm{~min}$. Resulting PCR amplicons were separated on $2 \%$ agarose gels to confirm the amplification of distinct bands and to assess the expression of each gene.

\section{Antimicrobial peptides}

Intron-spanning gene-specific primers for RT-PCR were designed, using the Vector NTI Advance ${ }^{\mathrm{TM}}$ software package (Invitrogen, Paisley, UK) and commercially synthesised (Invitrogen) for the following AMPs: LAP, TAP, BNBD4, DEFB5, and BBD119, BBD120, BBD122, $B B D 122 a, B B D 123, B B D 124, B B D 142$, as previously described in detail [17]. The AMPs selected were chosen because they had been identified previously in RNA extracted from a homogenate of uterine tissue [17]. For those gene transcripts identified in the endometrial cells in the present study, quantitative PCR was performed. Each reaction was carried out in duplicate in a total volume of $25 \mu \mathrm{l}$ with $2 \mu \mathrm{l}$ of cDNA $(20 \mathrm{ng} / \mu \mathrm{l}), 12.5 \mu \mathrm{l} 2 \times$ PCR master mix (Stratagene Corp., La Jolla, CA, USA), and $10.5 \mu \mathrm{l}$ primer $/ \mathrm{H}_{2} \mathrm{O}$. Optimal concentrations of primers 
Table I: Genebank accession numbers, product sizes and nucleotide sequence details of primers for RT-PCR analysis of mRNA expression of bovine TLR I to $I 0$.

\begin{tabular}{|c|c|c|c|c|}
\hline Gene & Primer & Sequence $5^{\prime}>3^{\prime}$ & Product Size (bp) & Accession No. \\
\hline \multirow[t]{2}{*}{ TLRI } & Sense & ACT TGG AAT TCC TTC TTC ACG A & 176 & NM 001046504 \\
\hline & Anti-sense & GGA AGA CTG AAC ACA TCA TGG A & & \\
\hline \multirow[t]{2}{*}{ TLR2 } & Sense & GGT TTT AAG GCA GAA TCG TTT G & 190 & NM 174197 \\
\hline & Anti-sense & AAG GCA CTG GGT TAA ACT GTG T & & \\
\hline \multirow[t]{2}{*}{ TLR3 } & Sense & GAT GTA TCA CCC TGC AAA GAC A & 195 & NM 001008664 \\
\hline & Anti-sense & TGC ATA TTC AAA CTG CTC TGC T & & \\
\hline \multirow[t]{2}{*}{ TLR4 } & Sense & CTT GCG TAC AGG TTG TTC CTA A & 153 & NM 174198 \\
\hline & Anti-sense & CTG GGA AGC TGG AGA AGT TAT G & & \\
\hline \multirow[t]{2}{*}{ TLR5 } & Sense & СCT CCT GCT CAG CTT CAA CTA T & 172 & AY634631 \\
\hline & Anti-sense & TAT CTG ACT TCC ACC CAG GTC T & & \\
\hline \multirow[t]{2}{*}{ TLR6 } & Sense & CCT TGT TTT TCA CCC AAA TAG C & 154 & NM 001001159 \\
\hline & Anti-sense & TAA GGT TGG TCC TCC AGT GAG T & & \\
\hline \multirow[t]{2}{*}{ TLR7 } & Sense & TCT TGA GGA AAG GGA CTG GTT A & 205 & DQ333225 \\
\hline & Anti-sense & AAG GGG CTT CTC AAG GAA TAT C & & \\
\hline \multirow[t]{2}{*}{ TLR8 } & Sense & TAA CCT TCG GAA TGT CTC CAG T & 232 & NM 001033937 \\
\hline & Anti-sense & GTG GGA AAT TCT GTT TCG ACT C & & \\
\hline \multirow[t]{2}{*}{ TLR9 } & Sense & CTG ACA CCT TCA GTC ACC TGA G & 156 & NM 183081 \\
\hline & Anti-sense & TGG TGG TCT TGG TGA TGT AGT C & & \\
\hline \multirow{2}{*}{$T L R I O$} & Sense & ATG GTG CCA TTA TGA ACC CTA C & 248 & NM 001076918 \\
\hline & Anti-sense & CAC ATG TCC CTC TGG TGT CTA A & & \\
\hline
\end{tabular}

were determined by titrating 100,300 and $900 \mathrm{nM}$ final concentrations of the forward and reverse primers. Real time qRT-PCR was performed using an MX3000P ${ }^{\circledR}$ quantitative PCR system (Stratagene Corp.) with the following cycling parameters: $95^{\circ} \mathrm{C}$ for $10 \mathrm{~min}$ followed by 40 cycles of $95^{\circ} \mathrm{C}$ for $30 \mathrm{sec}, 60^{\circ} \mathrm{C}$ for $1 \mathrm{~min}$ and $72^{\circ} \mathrm{C}$ for $30 \mathrm{sec}$ followed by amplicon dissociation. Resulting PCR amplicons were separated on $2 \%$ agarose gels to confirm the amplification of distinct bands and to assess the expression of each gene. The $2^{-\Delta \Delta \mathrm{Ct}}$ method was used to determine median fold changes in gene expression.

\section{MUC-I}

Total RNA was isolated as above, with intermediate oncolumn DnaseI digestion step (Qiagen, UK) and $1 \mu \mathrm{g}$ RNA was reverse transcribed using random decamer primers (RETROscript $^{\mathrm{TM}}$, Ambion, UK). Gene specific primer pairs were designed (Beacon Design 2.0, Premier Biosoft, USA) for MUC-1 (sense 5'-TGTGGTGGTAGAATTAACTC-3'; antisense 5'-ACTAACTCCGCTGATGG-3'; $120 \mathrm{bp}$ ) and $\beta$ ACTIN (sense 5'-ATCGGCAATGAGCGGTTCC-3'; antisense 5'-GTGTTGGCGTAGAGGTCCTTG-3'; 143 bp) as a reference amplicon. Amplification reactions were prepared in a volume of $20 \mu \mathrm{L}$ by adding $10 \mu \mathrm{L}$ of SYBRGreen Supermix $2 \times$ containing the Thermo-Start ${ }^{\circledast}$ DNA Polymerase (ABgene), $2.5 \mu \mathrm{L}$ of each primer $(4 \mu \mathrm{M})$ and 5 $\mu \mathrm{L}$ of serial dilutions of cDNA. RT-PCR amplifications were done in triplicate in 96-well optical reaction plates and run in the BioRad IQ iCycler; genomic DNA and RNA were used as positive and negative controls, respectively. Plates were heated first to $95^{\circ} \mathrm{C}$ for 15 min to activate the
Thermo-Start ${ }^{\oplus}$ DNA Polymerase enzyme and run for 50 cycles of $15 \mathrm{sec}$ at $95^{\circ} \mathrm{C}, 30 \mathrm{sec}$ at the optimal annealing temperature for each primer pair and $30 \mathrm{sec}$ at $72^{\circ} \mathrm{C}$, followed by 1 cycle of annealing at $55^{\circ} \mathrm{C}$ for $30 \mathrm{sec}$ and 1 cycle of denaturation at $95^{\circ} \mathrm{C}$ for $30 \mathrm{sec}$. To obtain the melting curves for each sample a final step of 40 cycles was performed for $10 \mathrm{~s}$ at $53^{\circ} \mathrm{C}$, increasing the set point temperature by $1{ }^{\circ} \mathrm{C}$ per cycle up to a maximum temperature of $94^{\circ} \mathrm{C}$. No amplicons were obtained using RNA directly in the PCR reaction. Relative quantification of gene expression data was determined from threshold cycle (Tc) values for each sample. Serial dilutions of cDNA were used to plot a calibration curve, and gene expression levels quantified by plotting Tc values on the curve. Expression levels were normalised with values obtained for the internal reference gene, and fold expression calculated as a ratio of transcript levels between treated and control samples.

\section{Acute phase proteins}

The concentration of haptoglobin was determined using a haptoglobin-haemoglobin binding assay as described previously [26]. The concentrations of serum amyloid were determined using an enzyme linked immunosorbent assay kit (Tridelta Development PLC, Dublin, Ireland) according to the manufacturer's instructions [26]. The limits of detection of the haptoglobin and serum amyloid A assays were $20 \mu \mathrm{g} / \mathrm{ml}$ and $0.33 \mu \mathrm{g} / \mathrm{ml}$, respectively. 


\section{Analysis}

Comparisons between treatment groups were made using ANOVA with Bonferroni Posthoc tests for normally distributed data, and Kruskal-Wallis tests for fold changes in gene expression. Significance was attributed when $P<$ 0.05 and data are reported as mean \pm SEM.

\section{Results}

\section{Toll-like receptors}

Gene transcripts for the ten mammalian TLRs were detected in bovine endometrium (Fig. 1). The level of expression did not differ significantly between whole endometrium collected from the body of the uterus, or the horn ipsilateral or contralateral to the corpus luteum. Endometrium contains endothelial, immune and blood cells, so the expression of TLRs was also examined in purified populations of epithelial and stromal cells, which were free of immune cell contamination as determined by the absence of mRNA for the pan-leukocyte marker CD45 (data not shown) [14]. Epithelial cells expressed TLRs 1 to 7 and 9; stromal cells expressed TLRs 1-4, 6, 7, 9 and 10 (Fig. 2).

E. coli is the first pathogen associated with uterine disease after parturition, inducing prostaglandin $\mathrm{E}_{2}$ secretion by epithelial cells [14]. So, a range of purified bacterial PAMPs were used to test if the TLRs associated with detection of bacteria were functional. Epithelial cells secreted more prostaglandin $\mathrm{E}_{2}$ than controls when treated with LPS, Pam3CSK4, or LTA, but not bacterial DNA (Fig. 3a). The PAMPs did not affect cell survival (Fig. 3b). The secretion of prostaglandin $\mathrm{E}_{2}$ was maximal for the O55:B5 LPS and this was greater than O111:B4 LPS ( $\mathrm{P}<0.05)$, so subsequent experiments used O55:B5 E. coli LPS as the standard PAMP to challenge cells.

\section{$T L R \frac{\text { Horn }}{\text { Ipsilateral Contralateral }}$ Body of Uterus}

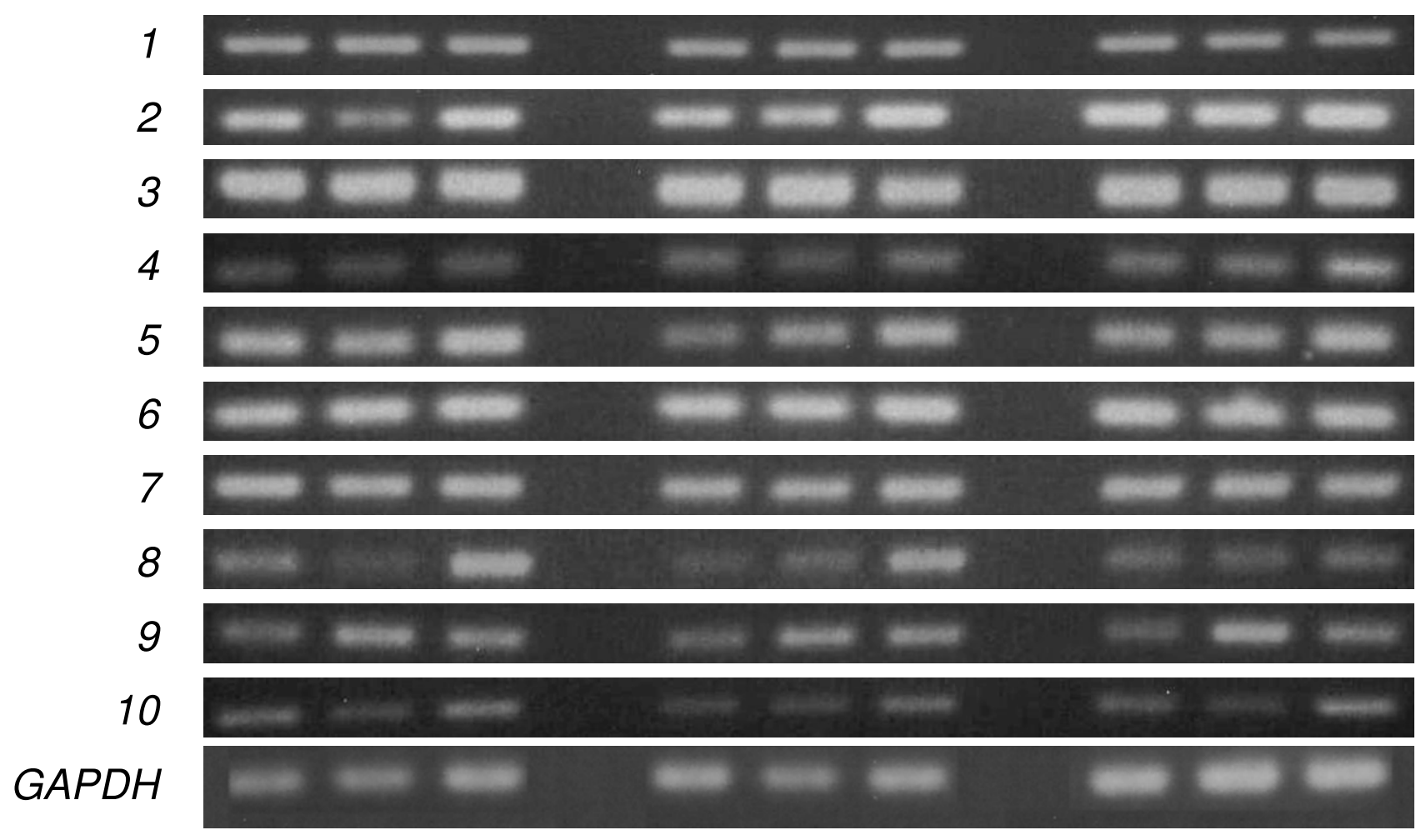

Figure I

TLR I to 10 gene expression by bovine endometrium collected from the uterine body, and the uterine horn ipsilateral or contralateral to the ovary containing the corpus luteum $(\mathbf{n}=\mathbf{3}$ per location). Also shown is GAPDH expression for comparison. RNA was isolated as described, and the resulting CDNA was analyzed by PCR for the presence of $T L R$ gene transcripts using the primer pairs described in Table I. 


\section{$T L R$}

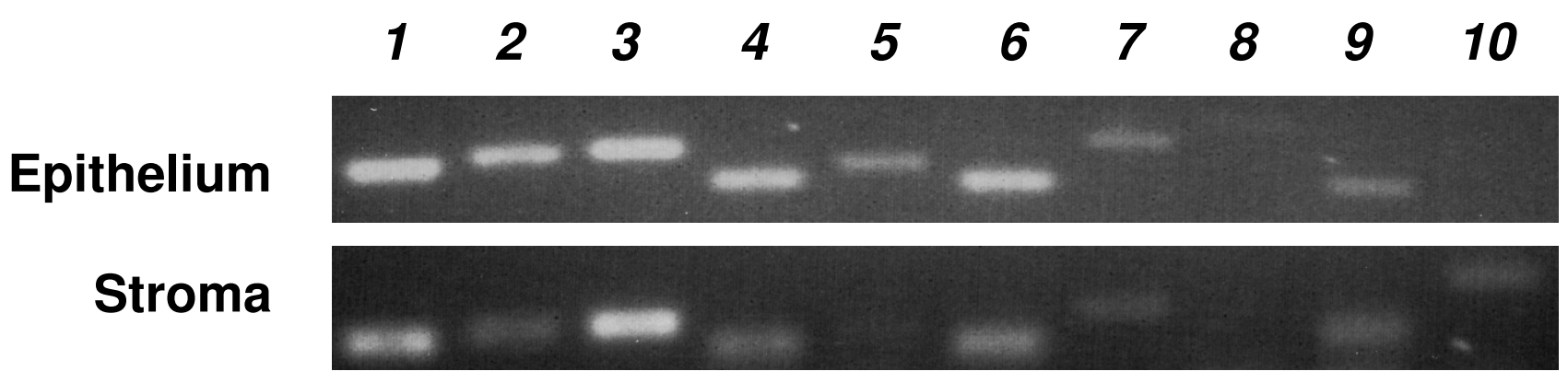

\section{Figure 2}

TLR I to 10 gene expression by bovine endometrial stromal and epithelial cells. Also shown is GAPDH expression for comparison. RNA was isolated as described, and the resulting CDNA was analyzed by PCR for the presence of TLR gene transcripts using the primer pairs described in Table I. A representative result is shown $(n=3)$.

\section{Antimicrobial peptides}

Gene transcripts for $L A P, T A P, B N B D 4$ and DEFB5 (Fig. 4a) and a weak expression of BBD123 were identified in epithelial cells by qRT-PCR, but there was no expression of $B B D 119, B B D 120, B B D 122, B B D 122 a, B B D 124$ and $B B D 142$. The stromal cells expressed $L A P$ and TAP (Fig. 4a) but did not express BNBD4, DEFB5, BBD119, $B B D 120, B B D 122, B B D 122 a, B B D 123, B B D 124$ and BBD142.

To test if $L A P, T A P, B N B D 4, D E F B 5$ or BBD123 were likely to be important for the response to bacterial infection, endometrial cells were challenged with LPS for $24 \mathrm{~h}$. Quantitative expression of LAP, TAP, BNBD4 and DEFB5 was increased relative to control in epithelial cells treated with LPS (Fig 4b). However, the expression of LAP, TAP, $B N B D 4$ or DEFB5 was not significantly changed in epithelial cells treated with LTA. In stromal cells treated with LPS there was no consistent change in AMP gene expression, but LTA reduced $L A P$ expression $(-2.39$ fold relative to control; $\mathrm{P}<0.05)$ and increased TAP expression (3.79 fold; $\mathrm{P}<0.05)$. Progesterone $(5 \mathrm{ng} / \mathrm{ml})$ did not affect AMP gene expression in epithelial or stromal cells (data not shown).

\section{Acute phase proteins}

The concentrations of haptoglobin were below the detectable limit of the assay and the concentrations of serum amyloid A just at the limit of detection for the test, with no differences in APP concentrations between supernatants from control and LPS treated stromal or epithelial cells.

\section{MUC-I}

Epithelial but not stromal cells expressed MUC-1 mRNA, and treatment of epithelial cells with LPS increased the expression of MUC-1 (Fig. 5). Luteal phase but not follicular phase concentrations of ovarian steroids reduced MUC-1 expression, although neither significantly affected the MUC-1 expression in response to treatment with LPS (Fig. 5).

\section{Discussion}

Bacterial infection of the female genital tract is common in cattle particularly after parturition, causing considerable disease, infertility and even mortality [2]. The endometrium is the first line of defence against these bacteria. Key components of innate immunity are the recognition of PAMPs by TLRs, leading to increased expression of AMPs and APPs $[11,15]$. In the present study endometrial samples expressed TLRs 1 to 10 , whilst purified populations of epithelial cells expressed TLRs 1 to 7 and 9, and stromal cells expressed TLRs 1 to 4, 6, 7, 9 and 10. The TLRs appeared to be functional as epithelial cells secreted prostaglandin $\mathrm{E}_{2}$ in response to bacterial PAMPs. In addition, the epithelial cells expressed AMPs, such as TAP and $L A P$, which were increased when the cells were treated with LPS. Although, there was no evidence of localised secretion of APPs, the epithelial cells also expressed MUC1. It appears that the epithelial cells play a critical role in the innate immune defence of the endometrium against bacteria that cause infertility.

The observation that bovine endometrial tissue expressed gene transcripts for all ten TLRs is similar to human endometrium $[27,28]$. Human endometrial TLR expression is regulated in part by the stage of the cycle [28]. In cattle, there is a progesterone concentration gradient 

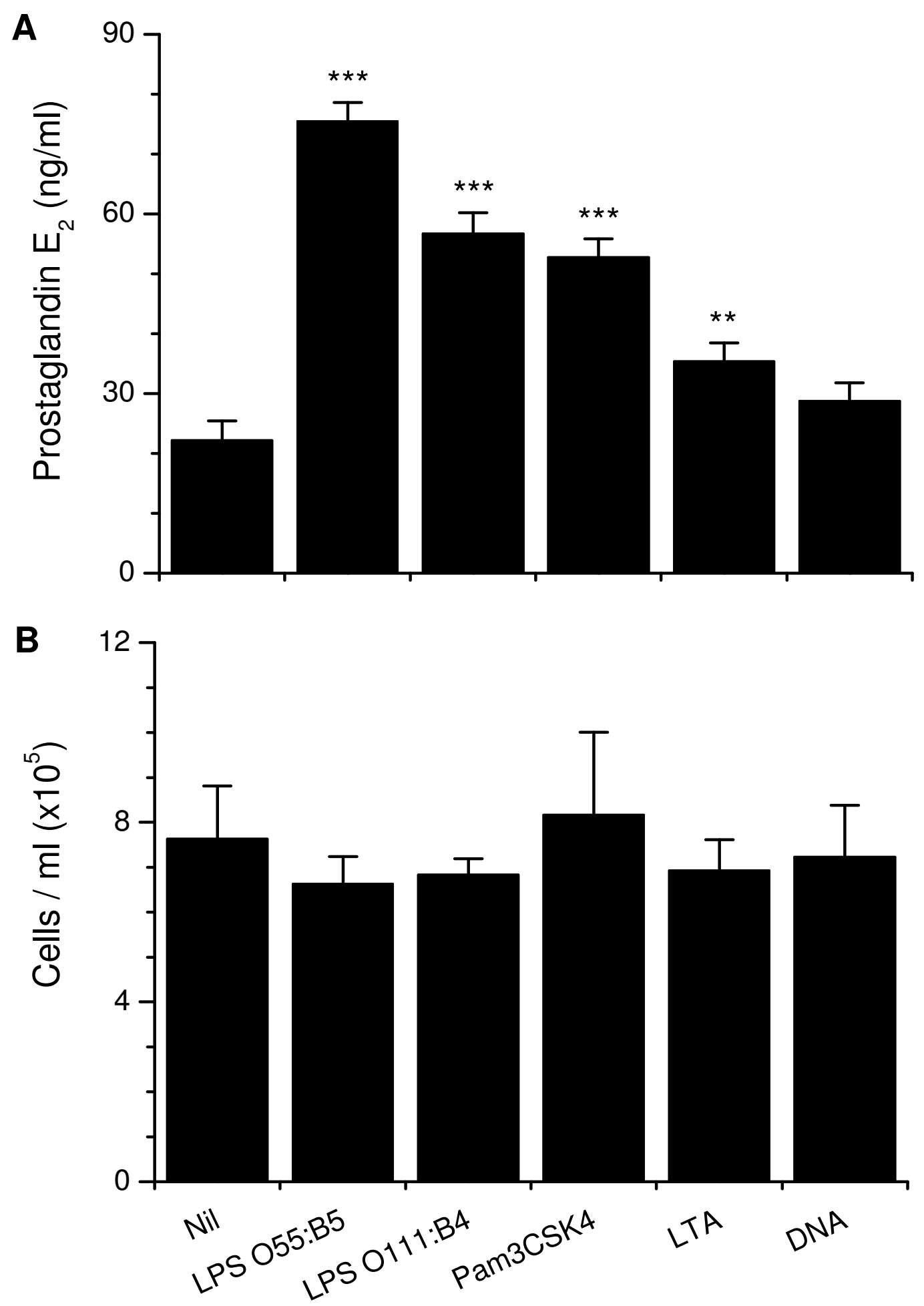

Figure 3

Endometrial epithelial cell (a) secretion of prostaglandin $E_{2}$ and (b) cells per $\mathrm{ml}$ after $24 \mathrm{~h}$ treatment with I $\mu$ g/ ml 055:B5 E. coli LPS, I $\mu \mathrm{g} / \mathrm{ml}$ ultrapurified O I I :B4 E. coli LPS, I $\mu \mathrm{g} / \mathrm{ml}$ Pam3CSK4, I $\mu$ g/ml lipoteichoic acid (LTA) from Staphylococcus aureus, or $5 \mu \mathrm{g} / \mathrm{ml}$ LPS-free E. coli DNA $(\mathbf{n}=6)$. Values differ significantly from control, *** $\mathrm{P}<0.001$, **P $<0.01$. 
A

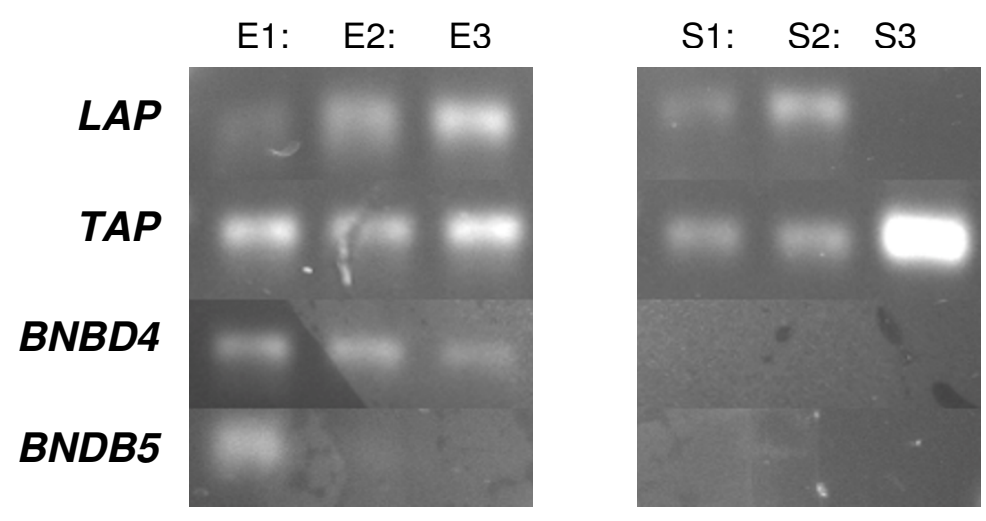

$\mathbf{B}$

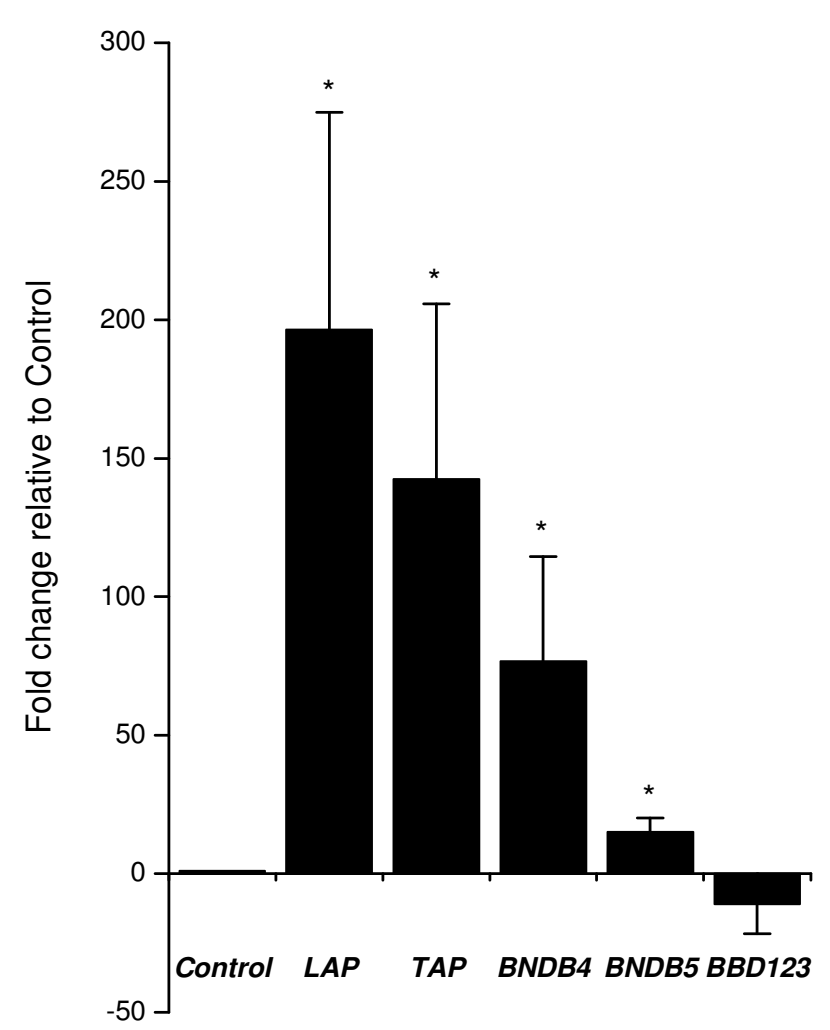

\section{Figure 4}

A analysis of antimicrobial peptide mRNA by epithelial and stromal cells. RNA was isolated as described, and the resulting CDNA was analyzed by RT-PCR for the presence of TAP, LAP, BNBD4 and DEFB5 gene transcripts as described in Materials and Methods. A representative result is shown $(n=3$ epithelial, EI-3, and stromal samples, $\mathrm{SI}-3)$. B analysis of antimicrobial peptide mRNA expression by epithelial cells. Endometrial epithelial cells were stimulated with I $\mu \mathrm{g} / \mathrm{ml} \mathrm{O} 55: \mathrm{B} 5 \mathrm{E}$. coli LPS for $24 \mathrm{~h}$ and harvested. TAP, LAP, BNBD4, DEFB5 and BBD/23 mRNA was quantified as described in Materials and Methods, and the data presented as fold change relative to gene expression in control cells $(n=3)$ Values differ significantly from control, $* \mathrm{P}<0.05$. 


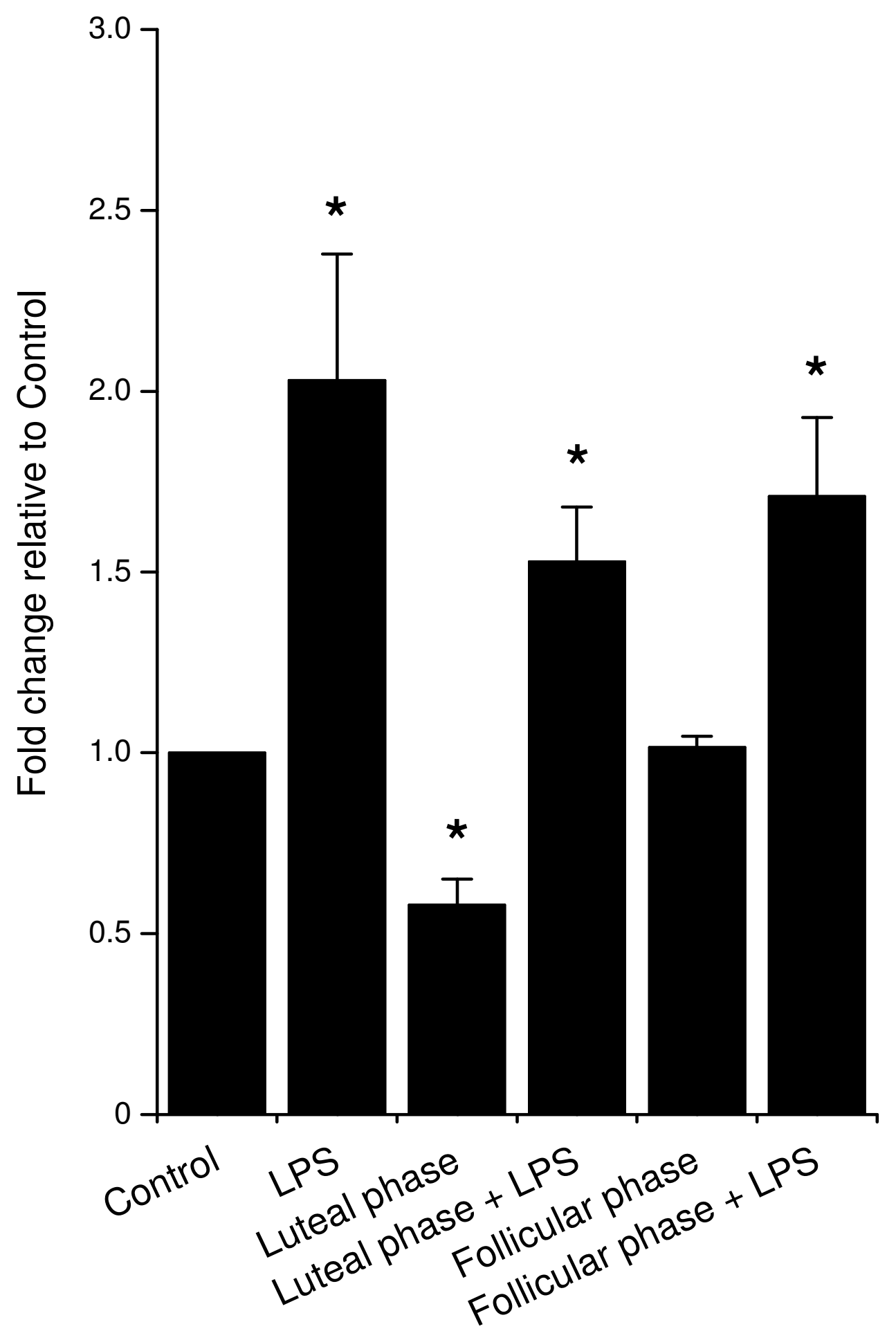

Figure 5

MUCI gene expression by epithelial cells. Cells were stimulated for $24 \mathrm{~h}$ with I $\mu \mathrm{g} / \mathrm{ml}$ O55:B5 E. coli LPS, luteal phase steroid concentrations $(5 \mathrm{ng} / \mathrm{ml}$ progesterone; $0.3 \mathrm{pg} / \mathrm{ml}$ oestradiol) or follicular phase steroid concentrations $(0.5 \mathrm{ng} / \mathrm{ml} \mathrm{pro}$ gesterone, $3 \mathrm{pg} / \mathrm{ml}$ oestradiol) alone or in combination, as indicated. mRNA was quantified as described in Materials and Methods, and the data presented as fold change relative to gene expression in control cells $(n=3)$. Values differ significantly from control, $* P<0.05$. 
across the uterus with the highest concentration at the tip of the horn ipsilateral to the corpus luteum and the lowest in the contralateral uterine horn [29]. Progesterone concentrations are important because progesterone suppresses immune defences in the bovine endometrium [9]. However, there were no obvious differences in gene transcript expression for any of the TLRs between different locations in the uterus.

Endometrial tissue samples contain several cell types including immune cells, so to test the concept that the endocrine cells have a role in immunity, we explored TLR expression in purified populations of epithelial and stromal cells, which are free of immune cell contamination in cattle [14]. The epithelial cell expression of TLRs 1 to 7 and 9, and stromal cells expression of TLRs 1 to 4, 6, 7, 9 and 10 , is similar to humans, where expression of TLR 1 to 9 has been reported in endometrial cell lines and in primary uterine epithelial cell cultures [30,31]. The epithelial cell expression of TLRs 1, 2, 4, 6 and 9 is important because they are required to detect bacterial PAMPs [11]. Bacterial infection is the predominant cause of uterine disease in cattle, and $E$. coli paves the way for other pathogens to cause damage to the endometrium, as well as disrupting endocrine function [5].

Bacterial PAMPs include LPS, LTA and DNA, so we tested the effects of these and the synthetic Pam3CSK4, to gain an insight into whether the cognate TLRs 1, 2, 4, 6 and 9 are functional in the epithelial cells. We chose to evaluate prostaglandin $E_{2}$ concentrations because it is a clear marker of bacterial infection in the bovine endometrium, as well as having an important endocrine role for regulating ovarian cycles and implantation [14,32]. E. coli or LPS switches epithelial cell secretion from prostaglandin $\mathrm{F}_{2 \alpha}$ to predominantly prostaglandin $\mathrm{E}_{2}$, mediated by the TLR4, MD2, CD14 signalling complex expressed by epithelial cells [14]. The predominant secretion of prostaglandin $E_{2}$ rather than prostaglandin $\mathrm{F}_{2 \alpha}$ is dependent on bacteria or PAMPs stimulating changes in the eicosaniod synthesis pathway, which includes phospholipases and prostaglandin synthases (Herath, unpublished data). This switch in function is important as prostaglandin $\mathrm{F}_{2 \alpha}$ initiates luteolysis whereas prostaglandin $\mathrm{E}_{2}$ is luteotrophic in ruminants [33]. Prostaglandin $\mathrm{E}_{2}$ is also an important component of the immune response to bacteria and regulates or suppresses inflammation in many tissues [34]. In the present study, LPS, LTA and Pam3CSK4 increased prostaglandin $\mathrm{E}_{2}$ secretion and none of the ligands affected epithelial cell survival, extending earlier observations that LPS was detected by human and bovine endometrial cells [14,35]. This stimulation of epithelial cell secretion of prostaglandin $E_{2}$ by several bacterial PAMPs may explain the association between uterine disease and extended luteal phases $[36,37]$. The secretion of prostaglandin $E_{2}$ was greater for the LPS from O55:B5 than O111:B4 E. coli, which may reflect the greater purity of the latter preparation. On the other hand, the O55:B5 LPS provided a potent PAMP to evaluate AMP expression in subsequent experiments.

The AMPs are an important arm of the innate immune defence against bacteria and TLRs mediate their induction in many mamalian tissues [15,38]. In the present study, bovine endometrial epithelial cells expressed several AMPs including $L A P, T A P, B N B D 4$ and DEFB5, whilst stromal cells expressed mainly $L A P$ and TAP. The predominant expression of TAP and $L A P$ by the epithelial cells is similar to the bovine mammary gland [39]. In humans, $\beta$ defensins have also been detected in the endometrium (HBD1, 2, 3 and 4), although there are some differences between studies $[40,41]$. In the present study, the epithelial cell AMP expression appeared to be of functional importance as the gene expression was increased in epithelial cells treated with LPS. The epithelial cells were consistently more responsive than the stromal cells, and LPS stimulated a greater response than LTA. Similarly in humans, endometrial HBD2 mRNA expression is increased after $24 \mathrm{~h}$ treatment with LPS, although unlike studies with human cells we did not find that progesterone regulated AMP expression in endometrial cells $[40,41]$. However, the substantial induction of epithelial LAP and TAP by LPS treatment probably reflects their defensive role against $E$. coli in cattle, and agrees with the concept that TLRs mediate induction of AMPs in response to PAMPs [15].

The concentrations of APPs, including haptoglobin and serum amyloid A, are substantially increased in the peripheral plasma of cow with bacterial infection of the endometrium [5]. Similar to the AMPs, the APPs such as haptoglobin and serum amyloid A provide non-specific protection against microbes [18]. Although usually produced by the liver, there is evidence of localised APP expression in the genital tract of rodents, regulated by the sex steroids $[19,20]$. However, in the present study the concentrations of haptoglobin and serum amyloid A proteins were barely detectable in epithelial or stromal cells, and not affected by treatment of cells with LPS. In vivo peripheral plasma concentrations are at least 25 times those of the culture supernatants [42]. So, it appears unlikely that localised secretion of APPs plays a major role in endometrial immunity in cattle.

MUC-1 is a glycosylated transmembrane protein commonly expressed by the epithelial cells of mucosal surfaces, including the reproductive tract, gut, testis and mammary gland [21,43]. MUC-1 is expressed in the human and ovine endometrium and has important roles in endometrial receptivity for embryo implantation, and is a marker of endometrial health and fertility in humans 
[22,23]. However, like AMPs and APPs, MUC-1 also has a role in protecting mucosal surfaces against bacteria. MUC1 sterically inhibits microbial access to the cell surface and regulates inflammation $[21,43]$. In the present study, MUC-1 expression was detected in the bovine epithelial cells and LPS increased the mRNA expression. In the human endometrium, MUC-1 is highly regulated by the ovarian sex steroids [44]. Although luteal phase concentrations of ovarian steroids decreased MUC-1 expression, follicular phase concentrations had no effect in the present study. Further, neither steroid combination affected the increase of $M U C-1$ expression stimulated by LPS. This is in contrast to the reduction in LPS-stimulated prostaglandin $\mathrm{E}_{2}$ secretion associated with progesterone or oestradiol [14].

\section{Conclusion}

In conclusion, the endometrium is an important first line of defence against invading bacteria that cause disease in cattle and endometrial samples expressed TLRs 1 to 10. The present study explored the concept that the endocrine cells play an important mechanistic role in the defence of the endometrium against bacteria. Purified populations of endometrial epithelial cells expressed TLRs 1 to 7 and 9, and stromal cells expressed TLRs 1 to 4, 6, 7, 9 and 10 . The TLRs appear to be functional as epithelial cells secreted prostaglandin $\mathrm{E}_{2}$ in response to bacterial PAMPs. In addition, the epithelial cells expressed AMPs, such as $T A P$ and $L A P$, and MUC-1, which were upregulated when the cells were treated with LPS. Thus, innate immune defence systems in the epithelial cells of the bovine endometrium are likely to play a key role in the prevention of endometrial infection with bacteria and mediate changes in endocrine function.

\section{Competing interests}

IMS holds research funding under a Department for Environment Food and Rural Affairs (DEFRA) LINK award from Pfizer Animal Health and the Biotechnology and Biological Sciences Research Council (BBSRC; F005121). Darren Davies was supported by a BBSRC CASE Studentship partly funded by Pfizer Animal Health (BBS/S/N/ 2005/12367). The remaining authors declare that they have no competing interests.

\section{Authors' contributions}

IMS was awarded the grants to fund the work, devised experiments, collated the data and wrote the manuscript. DD performed cell culture work and the molecular biology for TLR analysis. KGM and COF performed the AMP expression work and contributed to the manuscript. SH performed the cell culture PAMP treatments and prostaglandin measurements. PDE performed the acute phase protein measurements. DG, JOW, and RSC completed the
MUC-1 analysis and contributed to the manuscript. All authors read and approved the final manuscript.

\section{Acknowledgements}

Martin Sheldon is a BBSRC Research Development Fellow (Grant No. BB/ D02028X/I) and Darren Davies was a BBSRC CASE Student (BBS/S/N/

2005/ I 2367). The work was partly funded under a DEFRA LINK award by Pfizer Animal Health and BBSRC (F005I2I).

\section{References}

I. Sheldon IM, Lewis GS, LeBlanc SJ, Gilbert RO: Defining postpartum uterine disease in cattle. Theriogenology 2006, 65: I 5 I6-I530.

2. Sheldon IM, Williams EJ, Miller ANA, Nash DM, Herath S: Uterine diseases in cattle after parturition. Veterinary Journal 2008, I76: $|15-12|$.

3. Sheldon IM, Noakes DE, Rycroft AN, Pfeiffer DU, Dobson H: Influence of uterine bacterial contamination after parturition on ovarian dominant follicle selection and follicle growth and function in cattle. Reproduction 2002, I 23:837-845.

4. Donofrio G, Herath S, Sartori C, Cavirani S, Flammini CF, Sheldon IM Bovine herpesvirus 4 (BoHV-4) is tropic for bovine endometrial cells and modulates endocrine function. Reproduction 2007, I34:183-197.

5. Williams EJ, Fischer DP, Noakes DE, England GC, Rycroft A, Dobson $H$, Sheldon IM: The relationship between uterine pathogen growth density and ovarian function in the postpartum dairy cow. Theriogenology 2007, 68:549-559.

6. Donofrio G, Ravaneti L, Cavirani S, Herath S, Capocefalo A, Sheldon IM: Bacterial infection of endometrial stromal cells influences bovine herpesvirus 4 immediate early gene activation: a new insight into bacterial and viral interaction for uterine disease. Reproduction 2008, 136:361-366.

7. Wira CR, Grant-Tschudy KS, Crane-Godreau MA: Epithelial cells in the female reproductive tract: a central role as sentinels of immune protection. Am J Reprod Immunol 2005, 53:65-76.

8. King $A E$, Critchley HO, Kelly RW: Innate immune defences in the human endometrium. Reproductive Biology and Endocrinology 2003, I: II 6.

9. Lewis GS: Steroidal regulation of uterine resistance to bacterial infection in livestock. Reproductive Biology and Endocrinology 2003, I:II7.

10. Herath S, Dobson H, Bryant CE, Sheldon IM: Use of the cow as a large animal model of uterine infection and immunity. Journal of Reproductive Immunology 2006, 69: 13-22.

II. Akira S, Uematsu S, Takeuchi O: Pathogen recognition and innate immunity. Cell 2006, 124:783-80I.

12. Hirata T, Osuga $Y$, Hamasaki K, Hirota $Y$, Nose E, Morimoto C, Harada M, Takemura Y, Koga K, Yoshino O, Tajima T, Hasegawa A, Yano T, Taketani Y: Expression of toll-like receptors 2, 3, 4, and 9 genes in the human endometrium during the menstrual cycle. Journal of Reproductive Immunology 2007, 74:53-60.

13. Fazeli A, Bruce C, Anumba DO: Characterization of Toll-like receptors in the female reproductive tract in humans. Human Reproduction 2005, 20:1372-1378.

14. Herath S, Fischer DP, Werling D, Williams EJ, Lilly ST, Dobson H, Bryant CE, Sheldon IM: Expression and function of Toll-like receptor 4 in the endometrial cells of the uterus. Endocrinology 2006, I 147:562-570.

15. Selsted ME, Ouellette A): Mammalian defensins in the antimicrobial immune response. Nature Immunology 2005, 6:55I-557.

16. Diamond G, Zasloff M, Eck H, Brasseur M, Maloy WL, Bevins CL: Tracheal antimicrobial peptide, a cysteine-rich peptide from mammalian tracheal mucosa: peptide isolation and cloning of a cDNA. Proc Natl Acad Sci U S A 199I, 88:3952-3956.

17. Cormican P, Meade KG, Cahalane S, Narciandi F, Chapwanya A, Lloyd AT, O'Farrelly C: Evolution, expression and effectiveness in a cluster of novel bovine beta-defensins. Immunogenetics 2008, 60:147-156.

18. Baumann $\mathrm{H}$, Gauldie J: The acute phase response. Immunology Today 1994, I5:74-80.

19. Son DS, Arai KY, Roby KF, Terranova PF: Tumor necrosis factor alpha (TNF) increases granulosa cell proliferation: depend- 
ence on c-Jun and TNF receptor type I. Endocrinology 2004 , 145: $1218-1226$

20. Lebreton JP, Hiron M, Biou D, Daveau M: Regulation of alpha Iacid glycoprotein plasma concentration by sex steroids and adrenal-cortical hormones during experimental inflammation in the rat. Inflammation 1988, I 2:413-424.

21. Brayman M, Thathiah A, Carson DD: MUCI: a multifunctional cell surface component of reproductive tissue epithelia. Reproductive Biology and Endocrinology 2004, 2: I-9.

22. Johnson GA, Bazer FW, Jaeger LA, Ka H, Garlow JE, Pfarrer C, Spencer TE, Burghardt RC: MUC-I, integrin, and osteopontin expression during the implantation cascade in sheep. Biology of reproduction 200I, 65:820-828.

23. Horne AW, Lalani EN, Margara RA, Ryder TA, Mobberley MA, White JO: The expression pattern of MUCI glycoforms and other biomarkers of endometrial receptivity in fertile and infertile women. Mol Reprod Dev 2005, 72:216-229.

24. Ireland JJ, Murphee RL, Coulson PB: Accuracy of predicting stages of bovine estrous cycle by gross appearance of the corpus luteum. Journal of Dairy Science 1980, 63:155-160.

25. Rozen S, Skaletsky H: Primer3 on the WWW for general users and for biologist programmers. In Bioinformatics Methods and Protocols: Methods in Molecular Biology Edited by: Krawetz, Misener, S. Totowa, NJ: Humana Press; 2000:365-386.

26. Eckersall PD, Young FJ, Nolan AM, Knight CH, McComb C, Waterston MM, Hogarth C], Scott EM, Fitzpatrick JL: Acute phase proteins in bovine milk in an experimental model of Staphylococcus aureus subclinical mastitis. Journal of Dairy Science 2006, 89: |488-|50|.

27. Young SL, Lyddon TD, Jorgenson RL, Misfeldt ML: Expression of Toll-like Receptors in human endometrial epithelial cells and cell lines. American Journal of Reproductive Immunology 2004, 52:67-73.

28. Aflatoonian R, Tuckerman E, Elliott SL, Bruce C, Aflatoonian A, Li TC, Fazeli A: Menstrual cycle-dependent changes of Toll-like receptors in endometrium. Human Reproduction 2007, 22:586-593.

29. Weems CW, Lee CN, Weems YS, Vincent DL: Distribution of progesterone to the uterus and associated vasculature of cattle. Endocrinol Jpn 1988, 35(4):625-630.

30. Schaefer TM, Desouza K, Fahey JV, Beagley KW, Wira CR: Toll-like receptor (TLR) expression and TLR-mediated cytokinel chemokine production by human uterine epithelial cells. Immunology 2004, I I 2:428-436.

31. Schaefer TM, Fahey JV, Wright JA, Wira CR: Innate Immunity in the Human Female Reproductive Tract: Antiviral Response of Uterine Epithelial Cells to the TLR3 Agonist Poly(I:C). J Immunol 2005, I 74(2):992-1002.

32. Miller AN, Williams EJ, Sibley K, Herath S, Lane EA, Fishwick J, Nash DM, Rycroft AN, Dobson H, Bryant CE, Sheldon IM: The effects of Arcanobacterium pyogenes on endometrial function in vitro, and on uterine and ovarian function in vivo. Theriogenology 2007, 68:972-980.

33. Weems CW, Vincent DL, Weems YS: Roles of prostaglandins (PG) F2 alpha, EI, E2, adenosine, oestradiol-17 beta, histone-H2A and progesterone of conceptus, uterine or ovarian origin during early and mid pregnancy in the ewe. Reproduction Fertility and Development 1992, 4:289-295.

34. Narumiya S: Prostanoids in immunity: roles revealed by mice deficient in their receptors. Life Sciences 2003, 74:39I-395.

35. Hirata T, Osuga $Y$, Hirota $Y$, Koga K, Yoshino O, Harada M, Morimoto C, Yano T, Nishii O, Tsutsumi O, Taketani Y: Evidence for the presence of toll-like receptor 4 system in the human endometrium. I Clin Endocrinol Metab 2005, 90:548-556.

36. Poyser NL: The control of prostaglandin production by the endometrium in relation to luteolysis and menstruation. Prostaglandins Leukot Essent Fatty Acids 1995, 53:147-195.

37. Opsomer G, Grohn YT, Hertl J, Coryn M, Deluyker H, de Kruif A: Risk factors for post partum ovarian dysfunction in high producing dairy cows in Belgium: a field study. Theriogenology 2000, 53:84I-857.

38. Ganz T: Defensins and host defense. Science 1999, 286:420-42I.

39. Roosen S, Exner K, Paul S, Schroder JM, Kalm E, Looft C: Bovine beta-defensins: identification and characterization of novel bovine beta-defensin genes and their expression in mammary gland tissue. Mammalian Genome 2004, 15:834-842.
40. King AE, Fleming DC, Critchley HO, Kelly RW: Regulation of natural antibiotic expression by inflammatory mediators and mimics of infection in human endometrial epithelial cells. Molecular Human Reproduction 2002, 8:34I-349.

4I. King $A E$, Fleming DC, Critchley HO, Kelly RW: Differential expression of the natural antimicrobials, beta-defensins 3 and 4 , in human endometrium. Journal of Reproductive Immunology 2003, 59: I- 16.

42. Sheldon IM, Noakes DE, Rycroft A, Dobson H: Acute phase protein response to postpartum uterine bacterial contamination in cattle. Veterinary Record 200I, I 48: 172-175.

43. Beatty PL, Plevy SE, Sepulveda AR, Finn OJ: Cutting edge: transgenic expression of human MUCI in IL-10-/- mice accelerates inflammatory bowel disease and progression to colon cancer. J Immunol 2007, 179(2):735-739.

44. Horne AW, Lalani EN, Margara RA, White JO: The effects of sex steroid hormones and interleukin-I-beta on MUCI expression in endometrial epithelial cell lines. Reproduction 2006, 131:733-742.
Publish with BioMed Central and every scientist can read your work free of charge

"BioMed Central will be the most significant development for disseminating the results of biomedical research in our lifetime. "

Sir Paul Nurse, Cancer Research UK

Your research papers will be:

- available free of charge to the entire biomedical community

- peer reviewed and published immediately upon acceptance

- cited in PubMed and archived on PubMed Central

- yours - you keep the copyright
BioMedcentral 